\title{
Induction of Egr-1 expression by the retinoid AHPN in human lung carcinoma cells is dependent on activated ERK1/2
}

\author{
M Sakaue ${ }^{1,3}$, H Adachi ${ }^{1,3}$, M Dawson $^{2}$ and AM Jetten*,1 \\ ${ }^{1}$ Cell Biology Section, Laboratory of Pulmonary Pathobiology, National Institute \\ of Environmental Health Sciences, National Institutes of Health, Research \\ Triangle Park, North Carolina, NC 27709, USA \\ 2 Molecular Medicine Research Institute, Mountain View, California, CA 94043, \\ USA \\ ${ }^{3}$ These authors contributed equally to this research \\ * Corresponding author: AM Jetten, Cell Biology Section, Laboratory of \\ Pulmonary Pathobiology, National Institute of Environmental Health Sciences, \\ National Institutes of Health, Research Triangle Park, North Carolina, NC \\ 27709, USA. Tel: 919-541-2768; Fax: 919-541-4133; \\ E-mail: jetten@niehs.nih.gov
}

Received 19.6.00; revised 8.11.00; accepted 28.11.00

Edited by $\mathrm{C}$ Thiele

\begin{abstract}
The novel retinoid 6-[3-(1-adamantyl)-4-hydroxyphenyl]-2naphthalene carboxylic acid (AHPN/CD437) inhibits cell proliferation and is a very effective inducer of apoptosis in a variety of carcinoma cell lines. In order to obtain greater insight into the mechanism of AHPN-induced growth arrest and apoptosis, we began to examine AHPN-induced changes in gene expression by cDNA array screening using human lung carcinoma $\mathrm{H} 460$ cells. This analysis identified several AHPN-inducible genes, including the immediate-early genes Egr-1 and Nur77. AHPN was able to increase Egr-1 and Nur77 mRNA expression and protein in a variety of carcinoma cell lines. This induction appeared to be regulated at the transcriptional level and was specific for AHPN since an RAR- and an RXR-selective retinoid were inactive. These results suggest that the induction of Egr- 1 and Nur77 by AHPN is independent of nuclear retinoid receptors and involves a novel mechanism. Overexpression of Bcl-2, which inhibits AHPN-induced apoptosis but not growth arrest in human T cell lymphoma Molt-4 cells, did not block the induction of immediate-early gene expression. Treatment of $\mathrm{H} 460$ cells with AHPN induced activation of the p38 MAP-kinase but not the ERK1/2 signaling pathway. However, inhibition of the ERK1/2 signaling pathway by PD98059 blocked the induction of Egr-1 and Nur77 mRNA while the p38 MAPK inhibitor PD169316 had little effect. Expression of a dominant-negative ERK1 completely abolished the increase in Egr-1 mRNA. Treatment with MAPK inhibitors or expression of dnERK1 reduced but did not block AHPN-induced apoptosis. Our results suggest that the induction of Egr- 1 in $\mathrm{H} 460$ by AHPN requires active ERK1/2 and is independent of p38 activation. Egr-1, in cooperation with several other growth-suppressor
\end{abstract}

proteins, is likely involved in AHPN-induced inhibition of cell growth and cell death. Cell Death and Differentiation (2001) 8, $411-424$.

Keywords: retinoids; lung carcinoma; apoptosis; proliferation; MAPK

Abbreviations: AHPN, 6-[3-(1-adamantyl)-4-hydroxyphenyl]-2naphthalene carboxylic acid; Egr, Early-growth response gene; ERK, Extracellular signal-regulated kinase; MAPK, mitogenactivated protein kinase; RAR, retinoic acid receptor; RXR, retinoid $\mathrm{X}$ receptor

\section{Introduction}

Retinoids play an important role in the regulation of morphogenesis during lung development and in the control of proliferation, differentiation, and apoptosis of airway epithelial cells in vivo as well as in in vitro cell systems. ${ }^{1-3}$ It has been demonstrated that retinoids regulate surfactant protein synthesis in alveolar Type II cells ${ }^{4,5}$ and control cellular proliferation, differentiation, and the synthesis of mucins in tracheobronchial epithelial cells. ${ }^{6-9}$ The therapeutic value of retinoids in lung disease has been indicated by several studies. Retinoids have been shown to reverse squamous metaplasia and elastase-induced emphyse$\mathrm{ma},{ }^{3,10}$ promote differentiation in lungs of early infants, ${ }^{11}$ and inhibit the formation of second primary tumors in the lung. ${ }^{12}$

Many of the biological and molecular effects of retinoids are mediated by nuclear retinoid receptors. ${ }^{13}$ These receptors comprise two subfamilies, the retinoic acid receptors (RARs) and retinoid $X$ receptors (RXRs), each consisting of three different genes $(\alpha, \beta$ and $\gamma)$. RARs and RXRs alter gene expression by binding to specific response elements, RAREs or RXREs, respectively, in the regulatory regions of target genes. RARs and RXRs have been identified in many normal lung and airway epithelial cells as well as in lung carcinoma cells. ${ }^{8,14-17}$ The induction of the mucosecretory phenotype in normal tracheobronchial epithelial cells by retinoic acid is associated with an increase in the levels of $\operatorname{RAR} \beta$, suggesting a regulatory role for this receptor in this process. ${ }^{8,15}$ In many lung carcinoma cell lines, the inability of retinoic acid to induce $\operatorname{RAR} \beta$ is related to defects in the retinoid signaling pathway and may contribute to the malignant phenotype of these cells. ${ }^{14,15,18-20}$ RAR $\beta$ has been shown to mediate the growth-inhibitory effects of RA. The resistance of many lung carcinoma cells to the growth-inhibitory effects of retinoic acid may be due in part to defects in the retinoid signaling pathway. ${ }^{19,21,22}$ 
The actions of a number of retinoids, including 4(hydroxyphenyl)retinamide and 6-[3-(1-adamantyl)-4-hydroxyphenyl]-2-naphthalene carboxylic acid (AHPN/CD437), do not involve RARE- or RXRE-dependent transactivation and are not mediated by nuclear retinoid receptors. ${ }^{18,23-28}$ AHPN has been shown to be a very effective inhibitor of cell proliferation and to be able to induce apoptosis in a variety of cell lines, including melanoma, lymphoma, mammary and lung carcinoma cell lines. ${ }^{25,27-39}$ AHPN has been demonstrated to inhibit tumor formation in mice and is able to induce apoptosis in leukemia cells at low concentrations. ${ }^{29,33,40}$ These results may indicate a potential usefulness of AHPN in chemotherapy. Although AHPN can selectively bind to and activate the RAR receptor, ${ }^{41}$ several studies have provided evidence showing that its action is mediated through a unique, yet unknown, mechanism that is independent of the RAR/RXR signaling pathway. ${ }^{25,28-30}$

In order to identify genes that are important in the AHPN-induced growth arrest and apoptosis, we employed cDNA-array screening. This screening identified several AHPN-inducible genes most of which are early response genes and genes induced by DNA-damage agents or growth arrest. Egr-1 (Early-growth response gene 1; also named NGFI-A, Krox 24, Zif/268 or TIS8) ${ }^{42-46}$ is one of the AHPN-inducible genes identified in this study. Egr-1 is a nuclear phosphoprotein and a member of a $\mathrm{C}_{2} \mathrm{H}_{2}$-type zinc-finger family of transcription factors that control gene transcription by binding to GC-rich regulatory elements in the promoter region of target genes. Egr-1 has been reported to regulate numerous growth regulatory genes, such as c-myc and TGF- $\beta 1$, and to have an important function in negative growth control. ${ }^{47}$ We report that AHPN induces Egr-1 mRNA and protein in several carcinoma cell lines. The growth suppressor function of Egr-1 likely cooperates with other growth-inhibitory proteins in AHPN-induced growth arrest. The induction of Egr-1 by AHPN appears to be regulated at the transcriptional level and occurs through a mechanism that does not involve retinoid nuclear receptors. AHPN caused an activation of MAPK p38 but did not have any effect on the activation of the ERK1/2 signaling pathway. However, we demonstrated that the induction of Egr-1 by AHPN was dependent on activated ERK1/2 but did not require activated $\mathrm{p} 38$.

\section{Results}

\section{cDNA-array screening}

To obtain insight into the mechanism by which AHPN induces growth arrest and apoptosis, we used cDNA array screening to identify AHPN-mediated changes in gene expression. Human lung carcinoma $\mathrm{H} 460$ cells were treated with AHPN $(2.5 \mu \mathrm{M})$ or vehicle. After $8 \mathrm{~h}$ incubation, poly $(\mathrm{A})^{+}$ RNA was isolated and used in CDNA-array screening. Egr-1, Nur77, GADD45, MyD118, GAD153, c-jun, c-fos, interferon response factor (IRF)-1, tristetraproline (TTP), and the cdkinhibitor p21 ${ }^{\mathrm{WAF} 1 / \mathrm{Cip} 1}$ where among the genes identified by cDNA array screening. Differential expression of the genes

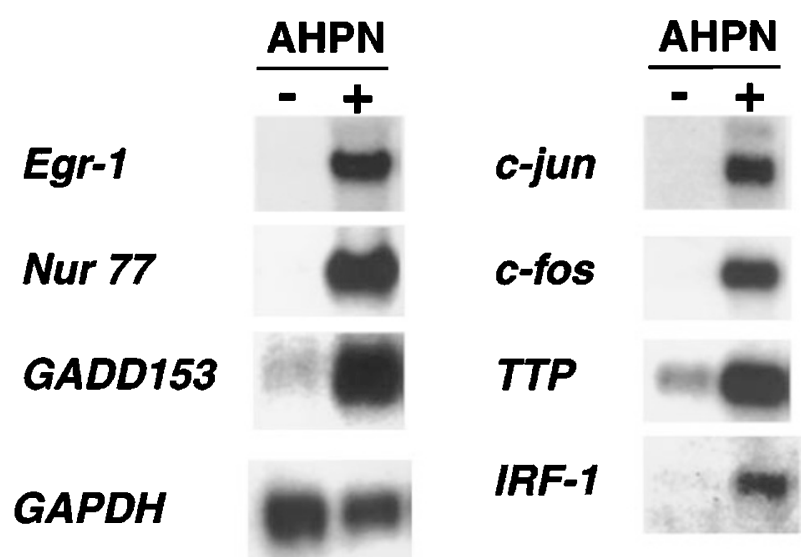

Figure 1 Northern blot analysis of several AHPN-inducible genes identified by CDNA array screening. Human lung carcinoma $\mathrm{H} 460$ cells were treated with $2.5 \mu \mathrm{M}$ AHPN $(+)$ or vehicle $(-)$. After $8 \mathrm{~h}$, cells were collected and total and poly $(A)^{+}$RNA isolated. RNA was examined by Northern blot analysis using radiolabeled probes for GAPDH and several differentially-expressed genes (Egr-1, Nur77, GADD153, c-jun, c-fos, TTP, and IRF-1) identified by cDNA array analysis

was confirmed by Northern blot analysis (Figure 1). Induction of MyD118, GADD45, Nur77, and cdk-inhibitor p21 WAF1/Cip1 by AHPN have been reported previously. ${ }^{27,31,34,48}$ It is interesting to note that many of the genes up-regulated by AHPN represent immediate-early response genes and genes induced after DNA damage. ${ }^{49,50}$ Moreover, many of these proteins have been implicated in the regulation of cell growth and apoptosis. ${ }^{34,47,51-53}$ In this study, we focus particularly on the characterization of AHPN-induced expression of Egr-1.

\section{Induction of Egr-1 mRNA occurs in many cell lines}

The induction of Egr-1 mRNA by AHPN was not limited to lung carcinoma $\mathrm{H} 460$ cells. AHPN increased the level of Egr-1 mRNA in lung carcinoma $\mathrm{H} 441$ and A549 cells (Figure 2A), human colorectal carcinoma RKO, and bladder carcinoma T24 cells (Figure 2B). In contrast to H460, H441, and A549 cells, untreated lung carcinoma H1355 cells expressed relatively high levels of Egr-1 mRNA that were increased only slightly by AHPN treatment. Egr-1 mRNA levels did not change significantly in Calu- 6 cells and mammary carcinoma MCF-7 cells. In H460 cells, AHPN induced Egr-1 mRNA expression at concentrations as low as $0.3 \mu \mathrm{M}$ (not shown).

In several cell lines, AHPN treatment also increased the expression of Nur77 mRNA (Figure 2). As shown for Egr-1, untreated $\mathrm{H} 1355$ cells expressed relative high levels of Nur77 mRNA that increased only slightly after AHPN treatment. Calu- 6 cells contained very low levels of Nur77 mRNA and its expression changed little after AHPN treatment. In T24 cells, AHPN increased expression of Egr-1 but not Nur77 mRNA. These results show that in the majority of the cell lines tested, there is a good qualitative correlation between Egr-1 and Nur77 expression; however, in some cell lines the expression of these two genes do not 


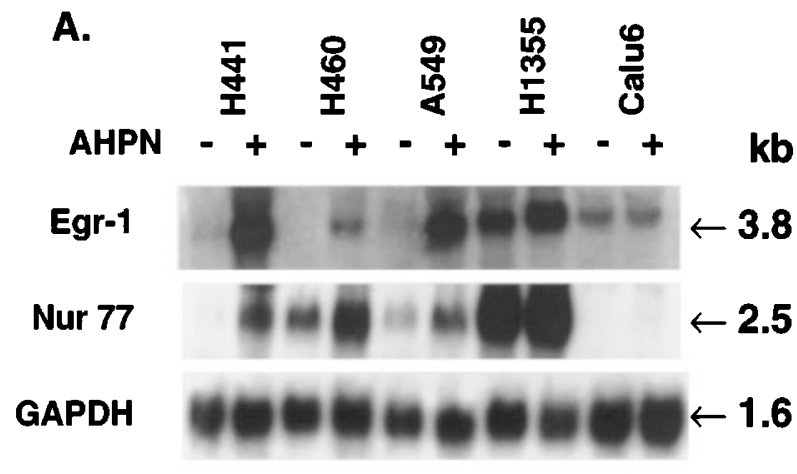

B.

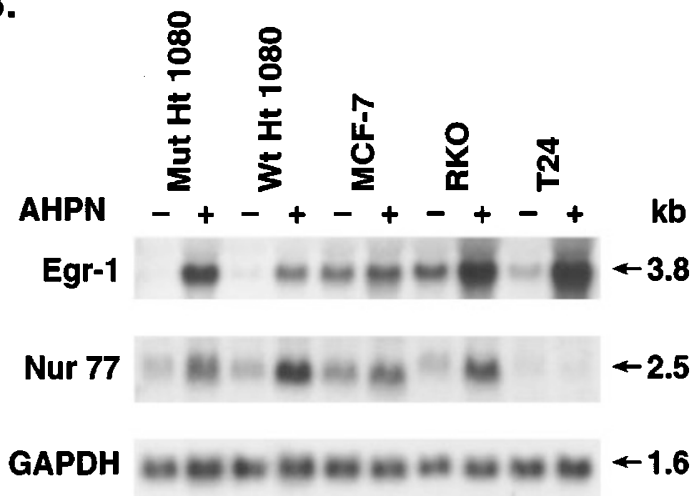

Figure 2 Comparison of the induction of Egr-1 and Nur77 mRNA by AHPN in several human carcinoma cell lines. Cells, treated with $2.5 \mu \mathrm{M}$ AHPN or vehicle, were collected and total RNA was isolated. RNA $(30 \mu \mathrm{g})$ was examined by Northern blot analysis using radiolabeled probes for Egr-1 and Nur77. A probe for GAPDH was used as a control. (A) Human lung carcinoma cell lines $\mathrm{H} 441, \mathrm{H} 460, \mathrm{~A} 549, \mathrm{H} 1355$ and Calu- 6 were treated for $8 \mathrm{~h}$ with AHPN $(+)$ or vehicle $(-)$. (B) Human fibrosarcoma Ht1080(p53wt) and $\mathrm{Ht1080}$ (p53mut), mammary carcinoma MCF-7, colon carcinoma RKO, and bladder carcinoma T24 cells were treated for $16 \mathrm{~h}$ with AHPN

coincide suggesting different mechanisms of regulation in these cells.

Expression of p53 has been reported to enhance the sensitivity to the growth-inhibitory and apoptosis-inducing effects of AHPN. ${ }^{54}$ We therefore, examined the effect of p53 on the induction of Egr-1 and Nur77 mRNA by AHPN. As shown in Figure $2 \mathrm{~B}$, AHPN was able to induce the expression of these genes in both human fibrosarcoma $\mathrm{Ht} 1080$ (p53wt) and $\mathrm{Ht1080}$ (p53mut) cells ${ }^{27}$ which contain wild-type or mutated p53, respectively (Figure $2 \mathrm{~B}$ ). These two cell lines are almost equally sensitive to AHPN-induced growth inhibition and cell death (not shown). These results suggest that the increase in Egr-1 and Nur77 expression, the induction cell death, and the inhibition of cell growth do not require p53wt. This is supported by observations showing that AHPN was able to induce Egr-1 and Nur77 mRNA very effectively in H441 cells containing a mutated p53 (Figure 2A). ${ }^{27}$ Comparison between the various parameters revealed that there is not a simple correlation between expression of p53wt, inhibition of proliferation, cell death and the expression of Egr-1 or Nur77 (Table 1).
Table 1 Comparison between the effect of AHPN on cell proliferation, cell death and the expression of p53, Egr-1 and Nur77 in several carcinoma cell lines

\begin{tabular}{lccccc}
\hline $\begin{array}{l}\text { Cell } \\
\text { line }\end{array}$ & $\begin{array}{c}\text { Growth } \\
\text { inhibition }\end{array}$ & $\begin{array}{c}\text { Cell } \\
\text { death }\end{array}$ & p53 & Egr-1 & Nur77 \\
\hline H441 & ++ & + & p53mt & ++ & ++ \\
H460 & ++ & ++ & p53wt & ++ & ++ \\
A549 & ++ & ++ & p53wt & ++ & ++ \\
H1355 & ++ & ++ & p53mt & + & + \\
Calu-6 & ++ & + & p53mt & NI & NI \\
Molt-4 & ++ & ++ & ND & + & NI \\
\hline
\end{tabular}

Cell lines exhibited little difference in AHPN-induced growth inhibition. ++ indicates relatively strong inhibition of cell proliferation or strong induction of cell death, Egr-1 or Nur77; + indicates relatively small induction. The relative level of induction was based on a comparison between several experiments. NI, not induced; ND, not determined

\section{Bcl-2, which inhibits apoptosis but not growth- arrest, does not block induction of Egr-1 mRNA}

Previously, we showed that AHPN induces apoptosis in human T cell lymphoma Molt- 4 cells. ${ }^{30}$ Overexpression of Bcl2 in these cells resulted in an inhibition of AHPN-induced apoptosis but did not prevent growth-arrest nor the accumulation of cells in the S-phase of the cell cycle. Therefore, we examined the effect of $\mathrm{Bcl}-2$ on the induction of several AHPN-inducible genes. As demonstrated in Figure 3, AHPN was able to induce the expression of Egr-1, GADD45, GADD153, MyD118, c-fos, and c-jun in both Molt4Hygr and Molt-4Bcl-2 cells. Although $\mathrm{Bcl}-2$ expression had some minor effects on the magnitude of the increase of some mRNAs, the results indicate that their induction is largely independent of $\mathrm{Bcl}-2$ expression and are upstream of $\mathrm{Bcl}-2$. Expression of most of these genes may be involved in growth inhibition as well as cell death and therefore, likely contributes to AHPN-induced growth-arrest in Molt-4Bcl-2 cells. In contrast to $\mathrm{H} 460$ cells, Molt-4Hygr cells expressed very low levels of Nur77 mRNA that remained unaltered after AHPN treatment, suggesting that its induction is not required for AHPN-induced growth arrest or apoptosis in these cells.

\section{Time-dependent induction of Egr-1 mRNA and protein}

The expression of Egr-1 mRNA was dependent on the length of AHPN treatment. In human lung carcinoma H460 cells, AHPN caused a transient induction of Egr-1 mRNA (Figure $4 A$ ). The level of Egr-1 mRNA increased within $2 \mathrm{~h}$ after the addition of AHPN, reached a maximum between 4 and $8 \mathrm{~h}$, and decreased by $24 \mathrm{~h}$ to that of untreated cells (Figure $4 \mathrm{C}$ ). A transient induction was also observed for the expression of Nur77 mRNA (Figure 4D). In contrast, in lung carcinoma A549 cells both Egr-1 and Nur77 mRNA expression steadily increased for up to $24 \mathrm{~h}$ after the addition of AHPN (Figure $4 \mathrm{~B}-\mathrm{D})$. The similarities in the time courses of Egr-1 and Nur77 induction suggest similarities in the mechanism by which they are regulated by AHPN.

The induction of Egr-1 mRNA expression in $\mathrm{H} 460$ cells by AHPN was associated with an increase in Egr-1 


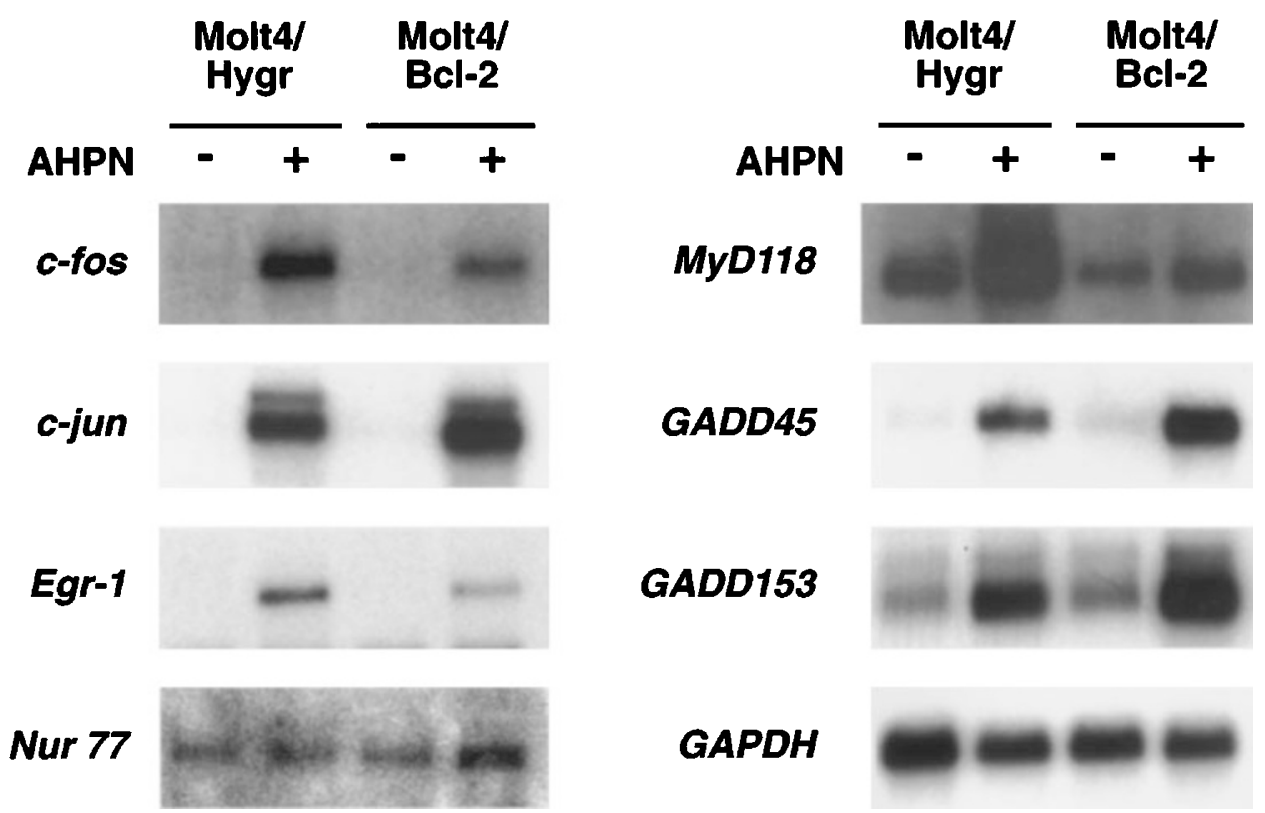

Figure 3 Effect of Bcl-2 on the induction of Egr-1 and several other early response genes. Human T cell lymphoma Molt-4-Hygr cells and Molt-4-Bcl12, overexpressing Bcl-2, were treated with $2.5 \mu \mathrm{M}$ AHPN for $8 \mathrm{~h}$. RNA was isolated and examined by Northern blot analysis for the expression of Egr-1, Nur77, c-jun, cfos, GADD45, GADD153, MyD118 and GAPDH mRNA

protein (Figure 5A). As with Egr-1 mRNA, the induction of the protein was transient. The level of Egr-1 protein increased $4 \mathrm{~h}$ after AHPN addition, reached a maximum between 8 and $16 \mathrm{~h}$, and after $24 \mathrm{~h}$, returned back to that of control cells. The time course of the induction of Egr-1 protein followed the increase in Egr-1 mRNA; however, the level of Egr-1 protein was maintained for a longer period of time than that of Egr-1 mRNA, reflecting differences in their half-life (Compare Figures $4 \mathrm{C}$ and $5 B)$. An increase in Egr-1 protein was also observed in $\mathrm{H} 441, \mathrm{~A} 549$, and $\mathrm{H} 1355$ cells. This increase was not always proportional to the level of Egr-1 mRNA indicating possible differences in posttranscriptional control between cell lines (Figure $5 \mathrm{C}$ ). As demonstrated for Egr-1 mRNA, little difference in the amount of Egr-1 protein was seen between AHPN-treated and untreated Calu-6 cells.

\section{Specificity of AHPN action}

AHPN has been reported to selectively bind to and activate the RAR $\gamma$ receptor. ${ }^{41}$ To determine whether the effect of AHPN is mediated through retinoid receptors, the effect of AHPN was compared with those of several other retinoids. As shown in Figure 6, Egr-1 protein in $\mathrm{H} 460$ cells did not increase upon treatment with the retinoid TTAB, which selectively binds to and activates all three RAR receptors, nor did treatment with the RXR-selective retinoid SR11217. These results demonstrate that the induction of Egr-1 and Nur77 mRNA expression is specific for AHPN and suggest that this action is not mediated through $\mathrm{RAR} / \mathrm{RXR}$ receptors but through a novel mechanism in agreement with previous studies. ${ }^{25,29,30,34}$ Many retinoids have been shown to exhibit anti-AP-1 activity. Our results suggest that the increase in Egr-1 expression by AHPN does not involve anti-AP-1 activity since the reportedly anti-AP-1 selective retinoid SR11302 had little effect on Egr-1 protein levels. This was further supported by the demonstration that the RAR- and RXR-selective retinoids, which also exhibit anti-AP-1 activity, were inactive as well.

\section{AHPN regulates Egr-1 mRNA expression at the transcriptional level}

Previous studies have reported that the AHPN-induced expression of several genes is related to increased RNA stability. ${ }^{27,34,36,48}$ However, in contrast to MyD118, GADD45, and p21, AHPN had little effect on the stability of Egr-1 and Nur77 mRNA in $\mathrm{H} 460$ cells (Figure 7). These observations are in agreement with the concept that the increase in the expression of these genes is regulated at the transcriptional level.

\section{AHPN-induced activation of MAPK}

Several studies have reported a role for MAPKs in the regulation of Egr-1. ${ }^{55-59}$ To determine whether the induction of Egr-1 by AHPN involves any of the MAPK signaling pathways, we determined the effect of AHPN on the activation of the ERK1/2 and p38 MAPKs. Figure 8 shows that control H460 cells contained relatively low levels of activated (phosphorylated) p38 and high levels of activated ERK1/2. Treatment with AHPN caused a rapid increase in the phosphorylation of p38 indicating that it is able to activate the p38 MAPK signaling pathway. In contrast, AHPN had little effect on the activation of ERK1/2. AHPN has also been demonstrated to cause activation of p38 MAPK in human myeloid leukemia HL60 cells. $^{60}$ 
A. $\mathbf{H 4 6 0}$

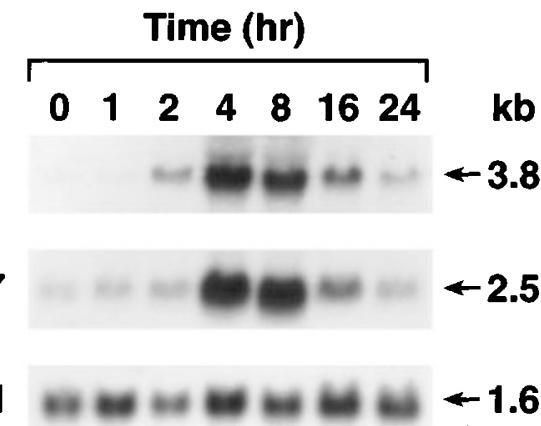

B. $\mathbf{A 5 4 9}$

Time (hr)

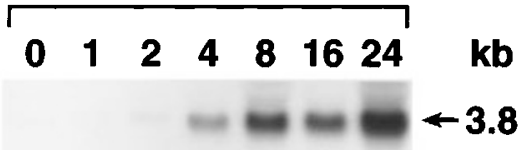

Egr-1 3.8

Nur $77=\mathrm{n}=\mathrm{e}$ e

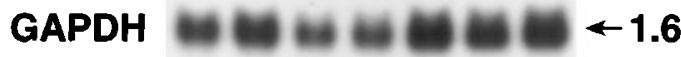

C.

D.
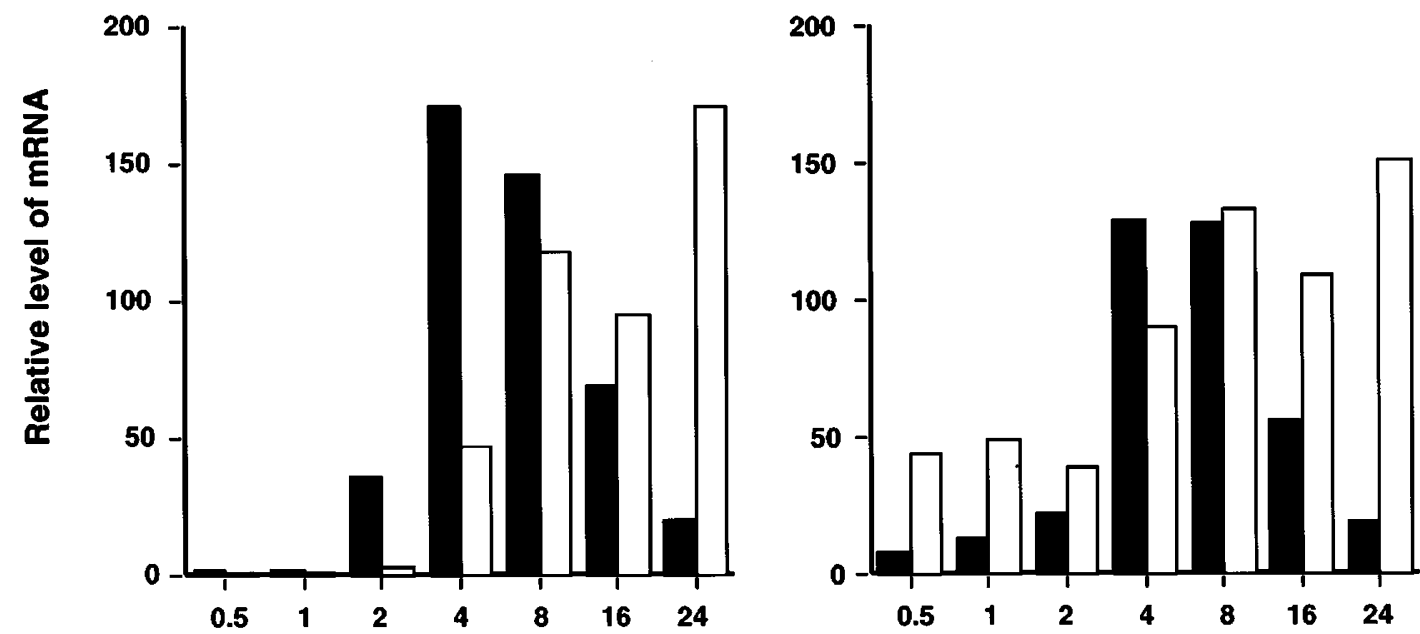

Time (h)

Time (h)

Figure 4 Time course of the induction of Egr-1 and Nur77 mRNA in human lung carcinoma H460 and A549 cells. (A,B) Cells were treated with $1 \mu \mathrm{M}$ AHPN for the period indicated. Total RNA was isolated and examined by Northern blot analysis using radiolabeled probes for Egr-1, Nur77, and GAPDH. (C,D) Hybridization signals were quantitated with a Phosphorlmage analyzer using ImageQuant software as described in Materials and Methods. The results are plotted as the relative level of Egr-1 (C) or Nur77 mRNA (D). Solid bars represent H460 and open bars A549 


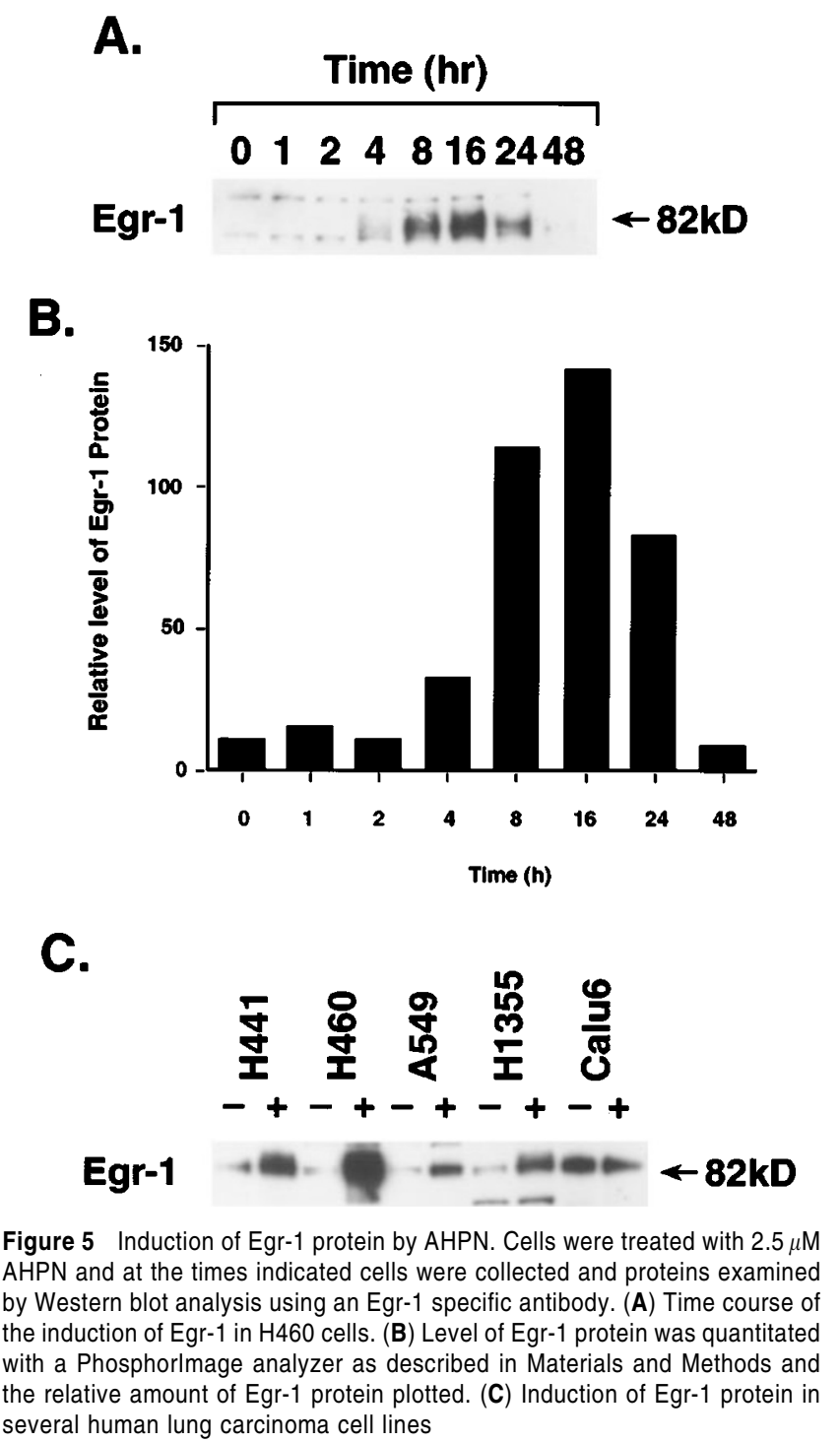

several human lung carcinoma cell lines

\section{Induction of Egr-1 by AHPN requires active ERK1/2}

To determine the role of $\mathrm{p} 38$ and ERK $1 / 2$ in the upregulation of Egr-1, H460 cells were treated with AHPN in the presence and absence of the p38 MAPK inhibitor PD169316 or the MEK1 inhibitors PD98059 or U0126. As shown in Figure 9, inhibition of MEK-1 by either U0126 or PD98059 reduced Egr1 mRNA expression in both AHPN-treated and control cells. In contrast, inhibition of $\mathrm{p} 38$ had little effect on the induction of Egr-1. The MAPK inhibitors had similar effects on AHPNinduced expression of Nur77 mRNA. These observations suggest that activation of the p38 signaling pathway is not involved in the AHPN-mediated increase in Egr-1 and Nur77 expression but that active ERK1/2 is needed for this induction. Neither PD98059 nor PD169316 affected the AHPN-induced increase in GADD45 mRNA expression which was reported to be regulated at the level of RNA stability. ${ }^{34,36}$ However, simultaneous treatment of H460 with PD169316 and U0126 increased the basal level of GADD45 mRNA expression in

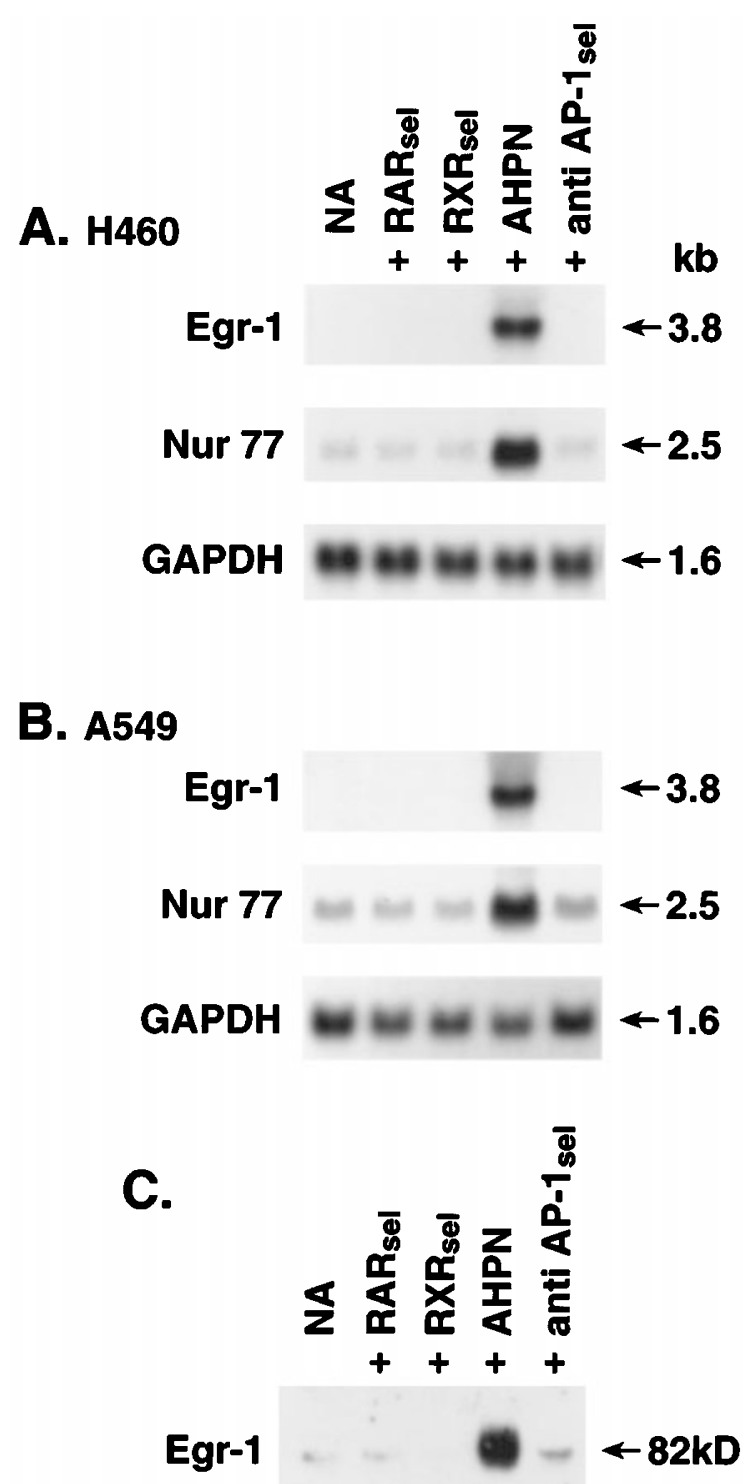

Figure 6 Specificity of the Egr-1 and Nur77 induction by AHPN. (A,B) H460 and A549 cells were treated with vehicle (0.1\% DMSO; NA) the RAR-selective retinoid TTAB $\left(\right.$ RAR $\left._{\text {se } 1}\right)$, the RXR selective retinoid SR12117 $\left(R_{X R_{\text {se } 1}}, A H P N\right.$, and the reported anti-AP-1-selective retinoid SR11302 (anti AP-1 se1 $_{\text {se }}$ ). After $8 \mathrm{~h}$, cells were collected and RNA was isolated. RNA was examined by Northern blot analysis using a radiolabeled probe for Egr-1, Nur77, and GAPDH. (C) H460 cells were treated as described under A,B. After $16 \mathrm{~h}$ treatment, cells were collected and protein examined by Western blot analysis using an antibody specific for Egr-1

untreated cells. These results suggest that the induction of GADD45 mRNA by AHPN is independent of ERK1/2 and p38 and appears to involve a mechanism that is different from that regulating Egr-1.

It was intriguing that although AHPN did not enhance the phosphorylation of $E R K 1 / 2$, inhibition of its activation by U0126 or PD98059 completely abolished the increase in Egr-1 mRNA indicating the importance of activated ERK1/2 in the upregulation of Egr-1. Active ERK1/2 could play a role in the control of Egr-1 at either the transcriptional or 
A.

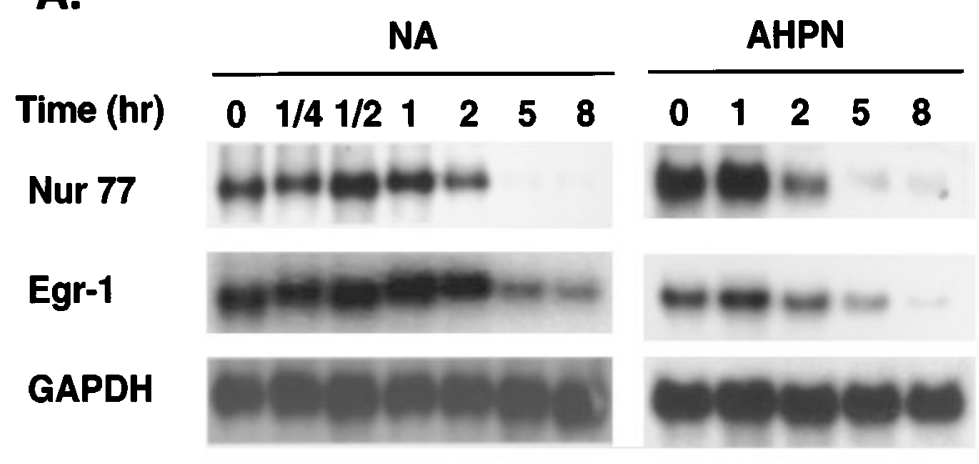

B.
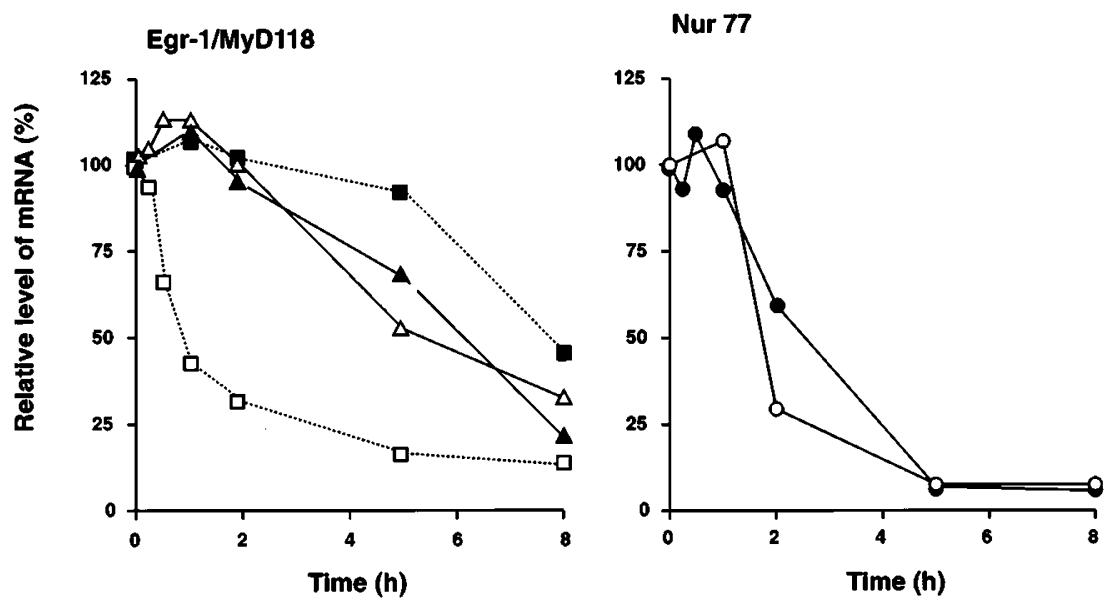

Figure 7 Effect of AHPN on the stability of Egr-1 and Nur77 mRNAs. (A) H460 cells were treated with AHPN for $8 \mathrm{~h}$ and subsequently with actinomycin D $(5 \mu \mathrm{g} / \mathrm{ml})$. At the indicated times, RNA was isolated and examined by Northern blot analysis with radiolabeled probes for Egr-1, Nur77 and GAPDH. Poly (A) ${ }^{+}$RNA was used in the case of untreated $\mathrm{H} 460$ cells and total RNA for AHPN treated cells. (B) Hybridization signals were quantitated with a Phosphorlmage analyzer using ImageQuant software as described in Materials and Methods. The results are plotted as the relative level of Egr-1 (triangles) or Nur77 (circles) mRNA (relative to the level of GAPDH and as the percentage of the signal at time 0 of actinomycin D addition). Experiment was performed twice with similar results. Results with MyD118 (squares) were shown for comparison and obtained from ref. 34. Open symbols, control cells; closed symbols, AHPN-treated cells

posttranscriptional level. Several studies have reported that MAPKs can regulate mRNA stability ${ }^{61}$ (and references therein). Similarly, active ERK1/2 may be needed to maintain the stability of Egr-1 mRNA. However, Figure 10 demonstrates that inhibition of ERK1/2 activation by U0126 had little effect on the stability of Egr-1 mRNA, indicating that active ERK $1 / 2$ is likely not required for maintaining the stability of Egr-1 mRNA. These results suggest that active ERK $1 / 2$ may be required for the transcriptional activation of Egr-1 by AHPN. A role for ERK1/2 in AHPN-induced Egr-1 expression is further supported by experiments examining the effect of dominant-negative ERK1 expression of the induction of Egr-1 in $\mathrm{H} 460$ cells. Figure 11A shows that expression of dominant-negative ERK1 (dn-ERK1) strongly inhibited the induction of Egr-1 and Nur77 mRNA. Expression of dn-ERK1 enhanced the survival of AHPNtreated $\mathrm{H} 460$ cells (Figure 11B). Likewise, the presence of PD98059 increased survival of AHPN (2.5 $\mu \mathrm{M})$-treated cells from 7.2 to $17.3 \%$ (Figure 11C). The presence of PD169316 had little effect. These results suggest that ERK $1 / 2$ can modulate the sensitivity to AHPN.

\section{Discussion}

In this study, we identified by cDNA array screening several AHPN-inducible genes encoding proteins that control cell growth and apoptosis. Tristetraprolin (TTP), ${ }^{62} \mathrm{c}$-jun, and c-fos belong to a group of immediate-early genes that are induced by a variety of stimuli. ${ }^{63}$ TTP binds to AU-rich elements and promotes deadenylation and destabilization of specific RNAs. ${ }^{64}$ MyD118, GADD45, Nur77, and cdk-inhibitor p21 have been previously reported to be induced by AHPN. ${ }^{25,27,28,34,36}$ MyD118, GADD45, and GADD153 are induced by a variety of conditions, including DNA-damaging agents, stress, and during terminal differentiation in a number of cell systems. ${ }^{50,65}$ All three genes have been shown to be 
A.

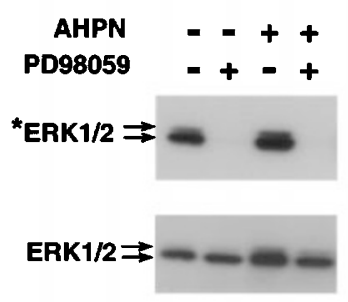

C.

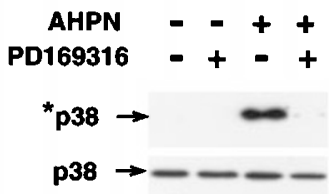

B.

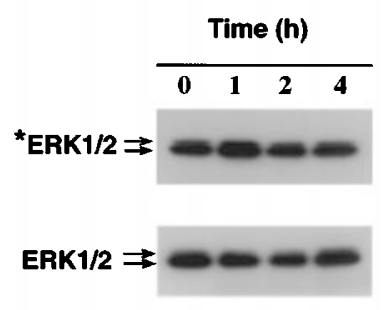

D.

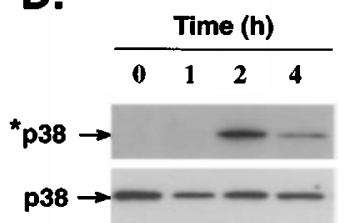

Figure 8 Effect of AHPN on the activation of ERK1/2 and p38 MAPKs in $\mathrm{H} 460$ cells. (A,C) $\mathrm{H} 460$ cells were treated with $2.5 \mu \mathrm{M}$ AHPN in the presence or absence of the MEK1/2 inhibitor PD98059 or the p39 MAPK inhibitor PD169316. After $2 \mathrm{~h}$ incubation, cells were collected and proteins examined by Western blot analysis using antibodies specific for total ERK1/2, phosphorylated (activated) ERK1/2 ( ${ }^{*}$ ERK1/2), total p38, and phosphorylated (activated) p38 ( ${ }^{*}$ p38) as described in Materials and Methods. (B,D) H460 cells were treated with $2.5 \mu \mathrm{M} \mathrm{AHPN}$ and at the times indicated cells were collected and proteins examined by Western blot analysis for the level of tota p38 and ERK $1 / 2$, or phosphorylated $\mathrm{p} 38$ and ERK $1 / 2$ protein

important modulators of growth arrest and apoptosis. IRF-1 is a transcriptional regulator of IFN-stimulated genes and plays a role in immune response and cell growth control by interferons. It can inhibit cell growth and induce apoptosis and loss of IRF-1 function has been reported to lead to malignant transformation, indicating that IRF-1 acts as a tumor suppressor. ${ }^{51,52}$ These and previous results suggest that AHPN-induced growth inhibition results from the increased expression of many growth-suppressor genes. ${ }^{25,27,28,30,31,34,36,54,66}$ Therefore, these growth-suppressor proteins may cooperate with each other in the inhibition of cell proliferation and the induction of apoptosis by AHPN.

In this study, we have been focusing largely on the regulation of Egr-1 by AHPN. Evidence showing that Egr-1 acts as a suppressor of cell proliferation is accumulating. ${ }^{47}$ Egr-1 has been reported to inhibit transformation in a variety of carcinoma cell lines; overexpression of Egr-1 has been demonstrated to reduce DNA synthesis and cell growth, and to induce apoptosis in some cell systems. ${ }^{47,67-69}$ In addition, Egr-1 is induced during terminal differentiation in embryonal carcinoma P19 cells, neuronal differentiation in pheochromocytoma PC12 cells, and differentiation in myoblastic leukemia HL-60 cells. The induction of Egr-1 mRNA and protein by AHPN in a number of carcinoma cell lines correlates with its growthinhibitory effects and is in agreement with the growthsuppressive function of Egr-1. Egr-1 has been reported to be significantly repressed in non-small cell lung carcinomas compared to normal tissue and a role for Egr-1 down-

A.

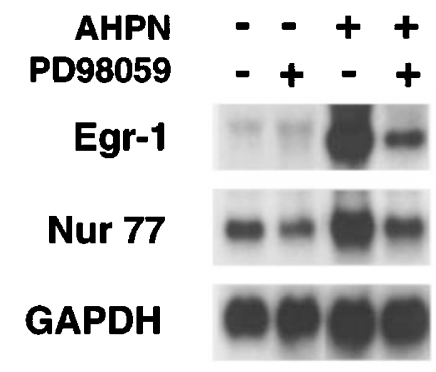

B.

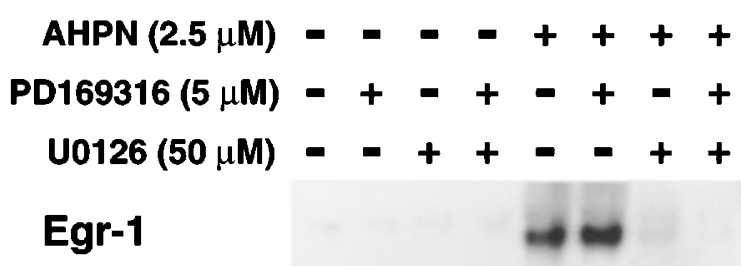

Nur 77

GADD45

\section{GAPDH}

Figure 9 Effect of p38 MAPK and MEK1/2 inhibitors on the induction of Egr1, Nur77 and GADD45 mRNA by AHPN. H460 cells were treated with $2.5 \mu \mathrm{M}$ AHPN in the presence or absence of the p38 MAPK inhibitor PD169316 (5 $\mu \mathrm{M})$ or the MEK1/2 inhibitors U0126 (50 $\mu \mathrm{M})(\mathbf{A})$ or PD98059 $(50 \mu \mathrm{M})(\mathbf{B})$. After $8 \mathrm{~h}$, RNA was isolated and examined by Northern blot analysis for the expression of Egr-1, Nur77, GADD45, and GAPDH mRNA

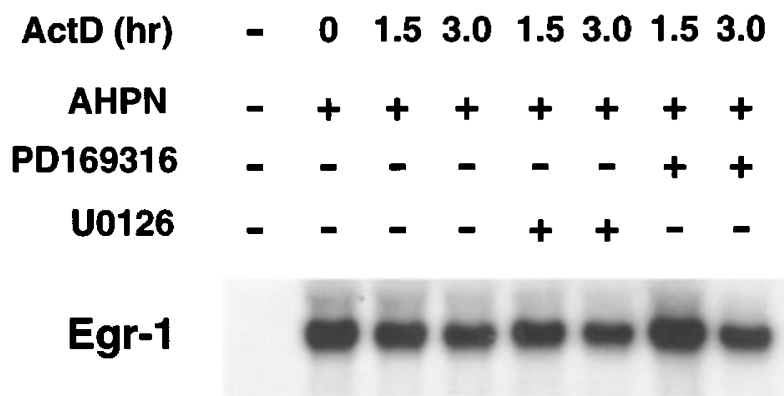

Nur 77

\section{GAPDH}

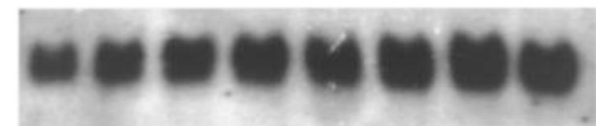

Figure 10 Effect of the inhibition of ERK1/2 and p38 MAPK on the stability of Egr-1 and Nur77 mRNA. H460 cells were treated with AHPN $(2.5 \mu \mathrm{M})$ for $8 \mathrm{~h}$ before actinomycin D $(5 \mu \mathrm{g} / \mathrm{ml})$ was added. After 30 min cells were treated with the p38 MAPK inhibitor PD169316 $(5 \mu \mathrm{M})$ or the MEK1/2 inhibitor U0126 $(50 \mu \mathrm{M})$. At the times indicated RNA was isolated and examined by Northern blot analsyis 
A.

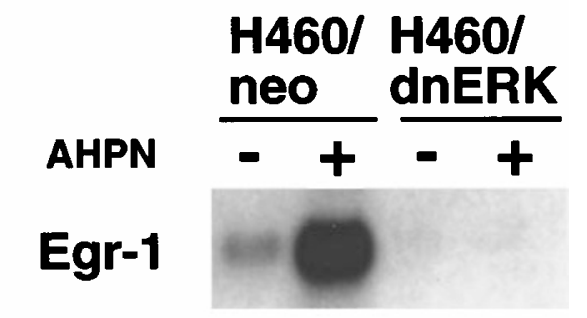

Nur 77

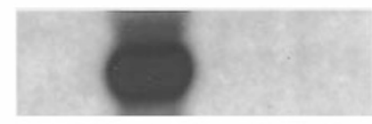

GAPDH

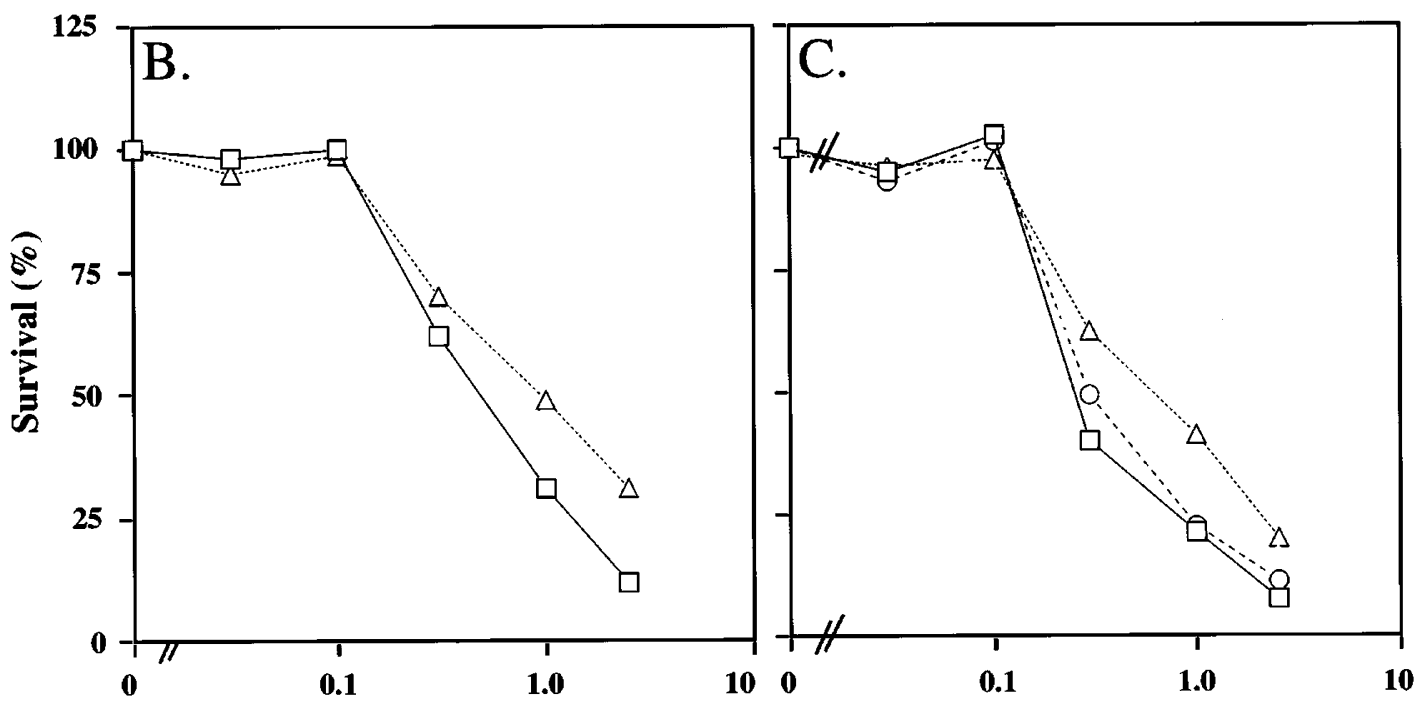

AHPN ( $\mu$ M)

Figure 11 Effect of dominant-negative ERK1 on the induction of Egr-1 and Nur77 expression by AHPN-in lung carcinoma H460 cells. RNA was isolated from H460-neo and H460-dnERK cells treated for $8 \mathrm{~h}$ with or without AHPN (2.5 $\mu \mathrm{M})$. RNA was examined by Northern blot analysis for expression of Egr-1, Nur77, and GAPDH mRNA. (B) Effect of dominant-negative ERK1 on AHPN-induced cell death by AHPN. H460-neo ( $\square$ ) and H460-dnERK ( $\triangle$ ) cells were treated with and without AHPN at the concentrations indicated. After 2 days, the per cent surviving cells was determined. (C) Effect of MAPK inhibitors on AHPN-induced cell death in $\mathrm{H} 460$ cells. Cells were treated with different concentrations of AHPN in the presence or absence of the p38 MAPK inhibitor PD169316 (5 $\mu \mathrm{M})$ ( $\mathrm{O}$ ) or the MEK1/2 inhibitor PD98059 $(50 \mu \mathrm{M})(\triangle)$. $\square$, control H460 cells. The per cent surviving cells was determined after $30 \mathrm{~h}$

regulation in the pathogenesis of lung cancer has been suggested. ${ }^{70}$ Although loss of chromosomal region 5 q31 containing the Egr-1 locus has been observed in small cell lung carcinoma, no gross alterations (deletions or rearrangements) in the Egr-1 gene were found, suggesting that the decreased expression could be due to changes in the transcriptional control of Egr-1 expression. ${ }^{70,71}$ In this study we show that Egr-1 mRNA and protein were expressed at relatively low levels in most lung carcinoma cell lines but are greatly induced by AHPN. Calu- 6 cells are an exception and expressed Egr-1 constitutively while AHPN treatment did not cause a further increase in Egr-1 mRNA or protein levels. These observations suggest an altered mechanism of Egr-1 regulation in Calu-6 cells.

Egr-1 belongs to a group of zinc-finger proteins with specificity for GC-rich DNA-response elements. ${ }^{47}$ This family further includes Egr-2 to -4 and members of the $\mathrm{Sp}-1$ subfamily. In a variety of gene promoters, Egr-1 and Sp-1 interact with overlapping binding sites and therefore are able to compete for binding to these DNA elements. In 
several instances, $\mathrm{Sp}-1$ activates transcription whereas binding of Egr-1 inhibits transactivation by $\mathrm{Sp}-1$. Sp-1 increases expression of many growth-stimulatory genes whereas expression of Egr-1 inhibits cell growth, possibly by interfering at least in part with $\mathrm{Sp}-1$ transactivation. The induction of Egr-1 by AHPN would result in changes in the ratio of these proteins and contribute to the mechanism by which AHPN causes growth arrest. It is interesting to note in this context that $\mathrm{Sp}-1$ protein is rapidly degraded in lung carcinoma cells after treatment with AHPN. ${ }^{72}$ Therefore, the increase in Egr-1 protein and decrease in Sp-1 may have a synergistic effect on the expression of certain genes and inhibition of cell growth.

The induction of Egr-1 expression can be mediated by p53-dependent and -independent mechanisms. The increase in Egr-1 expression by thapsigargin in melanoma cells was shown to depend on p53. ${ }^{67}$ In contrast, ionizing radiation was able to induce Egr-1 and apoptosis in prostate carcinoma PC3 cells lacking $p 53 .^{73}$ Our results show that Egr-1 mRNA is highly induced in human lung carcinoma H441 containing p53mt. Moreover, induction of Egr-1 in fibrosarcoma $\mathrm{Ht1080}$ (p53mut) cells containing p53mt was slightly higher than in $\mathrm{Ht1080}$ (p53wt) cells. These results suggest that p53 is not required for AHPNdependent induction of Egr-1 and that Egr-1 is controlled by a different mechanism.

Both the p38 and the ERK1/2 MAPK signaling pathways have been implicated in the regulation of Egr-1. ${ }^{55,59}$ Since AHPN induces activation of p38 MAPK in H460 cells, this activation could be causally related to the induction of Egr1. However, the p38 MAPK inhibitor PD169316 did not prevent the induction of Egr-1 by AHPN indicating that activation of p38 MAPK is not required for the induction of Egr-1 (Figure 12). In contrast, while AHPN treatment did not cause activation of ERK $1 / 2$, inhibitors of the activation of the ERK-signaling pathway blocked the increase in Egr-1 and Nur77 mRNA, suggesting that active ERK $1 / 2$ is required for the induction of Egr-1. This conclusion is supported by observations showing that expression of a dominant-negative ERK1 also blocked the induction of Egr1 mRNA. MAPKs have been reported to regulate gene expression at the transcriptional level through activation (phosphorylation) of transcription factors or by affecting the stability of specific mRNAs ${ }^{61}$ (and references therein). Our results show that inhibition of ERK $1 / 2$ activation does not effect the stability of Egr-1 mRNA, indicating that active ERK $1 / 2$ is not needed to maintain the stability of Egr-1 mRNA but is likely required for the transcriptional regulation of Egr- 1 by AHPN. Possibly, both transcriptional factors activated by ERK $1 / 2$, such as Elk-1, as well as signals generated by AHPN are essential for the AHPN-dependent induction of Egr-1 mRNA and affect the sensitivity of cells to AHPN growth inhibition (Figure 12). It is interesting to note that the ERK1/2 signaling pathway has been implicated in the induction of Egr-1 in several other cell systems, including hypoxia-exposed monocytes, ${ }^{57}$ nitric oxide-treated endothelial cells, ${ }^{74}$ and growth hormonetreated preadipocytes. ${ }^{58}$

Several studies have demonstrated that AHPN acts through multiple mechanisms. ${ }^{25,28,34-36,72}$ AHPN was

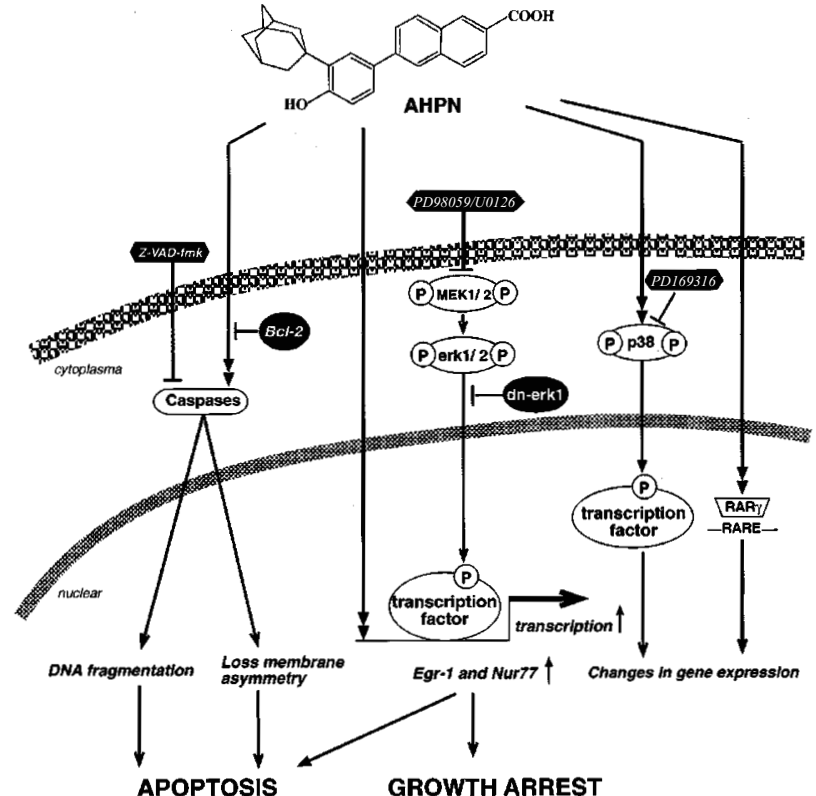

Figure 12 Schematic representation of the Egr-1 regulation by AHPN. AHPN action can be mediated by several signaling pathways, including activation of the RAR $\gamma$ receptor and activation of p38 MAPK. The induction of Egr-1 appears to be controlled at the transcriptional level but does not involve nuclear retinoid receptors or p38 activation and is independent of $\mathrm{Bcl}-2$ expression. Inhibition of the ERK signaling pathway either by MEK1 inhibitors PD98059 or U0126, or by expression of dnERK1 block Egr-1 induction by AHPN. Presence of PD98059 or expression of dnERK1 increase survival of AHPN-treated $\mathrm{H} 460$ cells. We hypothesize that the induction of Egr-1 expression by AHPN requires the cooperation between an ERK1/2dependent transcription factor and an AHPN-dependent signal. Although growth-inhibition can occur independently of apoptosis, ${ }^{30}$ ERK1/2 activity and growth-regulatory proteins, such as Egr-1, likely influence both AHPN-induced growth arrest and apoptosis

originally reported as a synthetic retinoid that selectively binds and activates the nuclear retinoid receptor $\mathrm{RAR}^{75}$ and at least some of AHPN-dependent changes in gene expression are likely mediated through this signaling pathway (Figure 12). However, AHPN-induced growth arrest, apoptosis, and the induction of several immediateearly genes, including Egr-1 and Nur77, appear not to involve nuclear retinoid receptors. This is supported by observations showing the lack of a correlation between the expression of RAR $\gamma$ and the growth-inhibitory effects of AHPN. ${ }^{15,27-31}$ The growth of small cell lung carcinoma and leukemia cells that do not express RAR $\gamma$ is effectively inhibited by AHPN. In addition, RAR and RXR-selective retinoids do not induce growth arrest or Egr-1 and Nur77 expression indicating that these effects are highly specific for AHPN. These results are in agreement with previous studies indicating that the action of AHPN is mediated by a novel mechanism. However, it cannot be ruled out that in certain cell lines binding and activation of RAR $\gamma$ either contributes to or modulates the growth-inhibitory action of AHPN.

Recent studies have demonstrated that AHPN can have a dramatic effect on the stability of certain mRNAs. AHPN causes an 8-10-fold increase in the stability of MyD118 
and GADD45 mRNA ${ }^{34,36}$ and the induction of p21 mRNA by AHPN has also been shown to be largely controlled at the level of its stability. ${ }^{48}$ However, in H460 cells AHPN had little effect on the stability of Egr-1 and Nur77 mRNA suggesting that the AHPN-induced expression of Egr-1 and Nur77 is at least in part regulated at the transcriptional level. Our results also demonstrate that up-regulation of Egr-1 and Nur77 by AHPN does not always occur in parallel. For example, AHPN induced Egr-1 expression in T24 and Molt-4Hygr cells while it did not have any effect on Nur77 mRNA expression, suggesting that in these cells Nur77 and Egr-1 expression are regulated differently. As shown in Table 1, there are no simple correlations between the expression of p53, Egr-1, and Nur77 and the induction of apoptosis and growth arrest.

Induction of apoptosis by AHPN is associated with increased caspase-3 activity. ${ }^{28,34}$ Expression of $\mathrm{Bcl}-2$ greatly inhibits caspase activation and apoptosis in $\mathrm{T}$ cell lymphoma Molt-4 cells but has only little effect on the growth-inhibitory action of AHPN. In this study, we show that expression of Bcl-2 inhibits neither the induction of Egr1 nor that of several other immediate-early genes (Figure 12). The caspase inhibitor ZVAD.fmk greatly inhibits DNAfragmentation but affects neither AHPN-induced growth inhibition $^{34}$ nor Egr-1 and Nur77 expression (Sakaue M, and Jetten AM, not shown). These results demonstrate that induction of Egr-1 occurs independently of caspase activation and $\mathrm{Bcl}-2$ expression. It is difficult to determine the precise role of Egr-1 in growth arrest and apoptosis since AHPN induces many genes that with similar functions. Previous studies indicated possible differences in the mechanism by which AHPN causes growth arrest and apoptosis. ${ }^{30}$ A recent study demonstrated that AHPN can disrupt mitochondrial potential in isolated mitochondria, suggesting that the induction of apoptosis by AHPN may not require de novo protein synthesis. ${ }^{33,76}$ Another study reported that translocation of Nur77 from the nucleus to mitochondria plays a critical role in the dissipation of mitochondrial potential induced by a variety of apoptotic signals, including AHPN. ${ }^{77}$ Possibly immediate-early proteins are not an absolute requirement but influence the sensitivity to AHPN induced cell death and growth arrest, as has been demonstrated for p53. ${ }^{54}$

In summary, we demonstrate that AHPN induces a cascade of changes in immediate-early genes that resembles those reported for DNA damage agents and stress. AHPN-induced growth arrest, and in many cell lines apoptosis, is associated with an increase in the expression of many genes, including Egr-1 and Nur77, that regulate proliferation and apoptosis. Table 1 suggests that there is no simple correlation between cell death, inhibition of cell proliferation, and expression of Egr-1, Nur77 and p53. It is likely that all these proteins are involved in some degree in AHPN-induced growth arrest and apoptosis, however, their importance and contribution may vary among cell lines and be obscured by the expression of other genes. The induction of Egr-1 and Nur77 by AHPN appears to be transcriptionally regulated and mediated by a novel mechanism that does not require retinoid nuclear receptors (Figure 12). Although we demonstrate that AHPN induces activation of p38 but not ERK1/2 MAPK, the induction of Egr-1 and nur77 requires activated ERK1/2 and not activated p38. Expression of dnERK or the presence of PD98059 enhances the survival of AHPN-treated H460 cells. This reduced responsiveness may in part be due to the diminished induction of growth suppressor genes, such as Egr-1. These results suggest that ERK1/2 can modulate the cell's sensitivity to AHPN.

\section{Materials and Methods}

\section{Materials}

The retinoid 6-[3-(1-adamantyl)-4-hydroxyphenyl]-2-naphthalene carboxylic acid (AHPN, also referred to as CD437) was described previously $^{75}$ and synthesized by Dr. M Dawson (MMRI, Mountain View, CA, USA). The RAR-selective (SRI-6751-84/TTAB, 4-(5,6,7,8tetrahydro-5,5,8,8-tetramethyl-2-anthracenyl)-benzoic acid), RXR-selective (SR11217, 4-[1-(5,6,7,8-tetrahydro-5,5,8,8,-tetramethyl-2naphthalenyl)-2-methyl-propenyl]-benzoic acid), and anti-AP1-selective (SR11302, (E)-3-methyl-9-(2,6,6-trimethylcyclohexenyl)-7-(4methyl-phenyl)-2,4,6,8-nonatetraenoic acid) retinoids ${ }^{78,79}$ were provided by Dr. M Dawson. All-trans retinoic acid was obtained from Hoffmann-La Roche, (Nutley, NJ, USA). Retinoids were dissolved in DMSO. Control cells received DMSO only. Actinomycin D was purchased from Sigma (St. Louis, MO, USA). The selective p38 MAP kinase inhibitor PD169316 and the MEK-1 inhibitor PD98059 were purchased from Calbiochem (San Diego, CA, USA). The MEK-1 inhibitor U0126 was purchased from Promega (Madison, WI, USA).

\section{Cell culture}

The human lung adenocarcinoma cell lines $\mathrm{NCl}-\mathrm{H} 441$ and $\mathrm{NCl}-\mathrm{H} 460$, alveolar carcinoma A549, anaplastic carcinoma Calu-6 and the human mammary cancer cell line MCF-7 were obtained from American Type Culture Collection (Rockville, MD, USA). The human lung adenocarcinoma NCl-H1355 cells were provided by Dr. A Gazdar (Austin, TX, USA). Human T cell lymphoma Molt-4Hygr and Molt-4-Bcl2 were described previously. ${ }^{30,80}$ The human fibrosarcoma cell line $\mathrm{Ht} 1080$, a variant $\mathrm{Ht} 1080$ containing a mutant $\mathrm{p} 53$, and the human colorectal cancer cell line RKO were obtained from Dr. Gloria Preston (NIEHS). The human bladder cancer cell line T24 was obtained from Dr. T Eling (NIEHS). All cell lines, except for $\mathrm{Ht} 1080$ and RKO, were cultured in RPMI-1640 medium supplemented with $10 \%$ heat-inactivated fetal bovine serum, $2 \mathrm{mM}$ L-glutamine, 100 units penicillin and $100 \mu \mathrm{g}$ streptomycin. The Ht1080 and the RKO cells were grown in Dulbecco's modified Eagle Medium (DMEM) supplemented with 10\% fetal bovine serum. All cells were Mycoplasma free and were cultured under the condition of $5 \% \mathrm{CO}_{2}$ humid air at $37^{\circ} \mathrm{C}$.

\section{Expression of dominant-negative ERK}

The expression vector pCMV-dnERK, encoding a dominant-negative form of ERK1 MAP kinase, was obtained from Dr. R Khosravi-Far. $\mathrm{H} 460$ cells were plated in 6 -well dishes $\left(2 \times 10^{5}\right.$ cells per well) $16 \mathrm{~h}$ prior to transfection. PCMV-dnERK or the neomycin phosphotransferase (neo) gene expression plasmid (pCB6) was transfected into cells using 1,3-di-oleoyloxy-2-(6-carboxy-spermyl)-propylamide (DOSPER, Roche) as directed by the manufacturer's protocol. Twenty-four hours after transfection, cells were treated with G418 (Gibco, $500 \mu \mathrm{g} / \mathrm{ml})$ to 
select for neomycin-resistant cells. H460 cells expressing dnERK or neo gene only are referred to as H460-dnERK and H460-neo, respectively. Detailed characterization of these cell lines will be described elsewhere.

\section{cDNA-array analysis}

Human lung carcinoma $\mathrm{H} 460$ cells were treated with $2.5 \mu \mathrm{M}$ AHPN or vehicle (DMSO) for $8 \mathrm{~h}$. Total RNA was isolated using Tri-Reagent (Sigma, St. Louis, MO, USA) according to the manufacturer's protocol. Poly $(A)^{+}$RNA was subsequently prepared by PolyAtract (Promega) and treated with DNase I. Analysis of the Atlas cDNA Expression Arrays (Clontech) was carried out according to the manufacturer's directions. Briefly, RNAs were reverse-transcribed using MMLVreverse transcriptase in the presence of $\left[\alpha_{-}{ }^{32} \mathrm{P}\right] \mathrm{dATP}$. The radiolabeled cDNA probes were hybridized overnight to Atlas cDNA Array membranes in ExpressHyb hybridization solution (Clontech). After washing in $0.1 \times \mathrm{SSC}$ plus $0.5 \%$ SDS at $68^{\circ} \mathrm{C}$, membranes were subjected to autoradiography at $-70^{\circ} \mathrm{C}$. Differentially expressed cDNAs were confirmed by Northern blot analysis.

\section{Northern blot analysis}

Total RNA $(30 \mu \mathrm{g})$ or poly $(\mathrm{A})^{+}$RNA $(2 \mu \mathrm{g})$ was separated by electrophoresis on a formaldehyde $1.2 \%$ agarose gel, blotted to a Nytran Plus membrane (Schleicher \& Schuell, Keene, NH, USA), and UV-crosslinked as described previously. ${ }^{30}$ Hybridizations were carried out for $1-2 \mathrm{~h}$ at $68^{\circ} \mathrm{C}$ using QuikHyb ${ }^{\circledR}$ reagent (Stratagene, La Jolla, CA, USA), blots were washed twice with $2 \times$ SSC, $0.05 \%$ SDS for $15 \mathrm{~min}$ at room temperature and subsequently with $0.5 \times \mathrm{SSC}, 0.1 \%$ SDS at $65^{\circ} \mathrm{C}$ for $30 \mathrm{~min}$. Autoradiography was carried out with Hyperfilm-MP (Amersham) at $-70^{\circ} \mathrm{C}$ using double intensifying screens. The cDNA probe for Egr-1 used in Northern analysis was obtained through differential display. ${ }^{34}$ The cDNA probe for Nur77 was obtained from Dr. C Chang, (Glaxo Wellcome, NC, USA). A $1.26 \mathrm{~kb}$ fragment of the chicken glyceraldehyde-3-phosphate dehydrogenase gene (GAPDH) was used as a control probe.

\section{RNA stability assay}

$\mathrm{H} 460$ cells grown for $8 \mathrm{~h}$ in the presence or absence of $2.5 \mu \mathrm{M}$ AHPN were treated with actinomycin $\mathrm{D}(5 \mu \mathrm{g} / \mathrm{ml})$ and, at different time intervals, cells were collected and RNA isolated. For RNA stability assay, total RNA from AHPN-treated cells and poly $(A)^{+}$RNA from control $\mathrm{H} 460$ cells were examined by Northern blot analysis using radiolabeled probes for Egr-1, Nur77, or GAPDH. Hybridization signals were quantitated with a Phosphorlmage analyzer (STORM 860; Molecular Dynamics, Sunnyvale, CA, USA) using ImageQuant software (Molecular Dynamics).

\section{Western blot analysis}

Cells were washed in PBS and then collected in sample buffer $(60 \mathrm{mM}$ Tris- $\mathrm{HCl}, \mathrm{pH} 6.8,2 \%$ SDS, $10 \%$ glycerol, $10 \mathrm{mM}$ DTT, $1 \mathrm{mM}$ phenylmethylsulfonyl fluoride, aprotinin, and leupeptin) and phosphatase inhibitor mixture I and II (Sigma). Proteins were examined by Western blot analyses. Primary antibodies against Egr-1 and ERK1/2 were purchased from Santa Cruz Biotechnology (San Diego, CA, USA). Antibodies against phospho-p44/p42 ERK1/2, phospho-p38, and p38 were obtained from New England Biolabs (Beverly, MA, USA). Peroxidase-conjugated anti-goat or anti-rabbit $\operatorname{lgG}$ from Chemicon (Temecula, CA, USA) was used as secondary antibody.
Antibodies were diluted in PBS containing 1 or $5 \%$ milk powder and $0.05 \%$ Tween 20 . Detection was carried out using Super Signal Chemiluminescent Substrate; Luminol and Peroxide were purchased from Pierce (Rockford, IL, USA).

\section{Acknowledgements}

This research was supported in part by the Japanese Society for the Promotion of Science.

\section{References}

1. Zachman RD (1995) Role of vitamin A in lung development. J. Nutr. 125: 1634S$1638 \mathrm{~S}$

2. Mendelsohn C, Lohnes D, Decimo D, Lufkin T, LeMeur M, Chambon P and Mark $M$ (1994) Function of the retinoic acid receptors (RARs) during development (II). Multiple abnormalities at various stages of organogenesis in RAR double mutants. Development 120: 2749-2771

3. Jetten AM, Nervi C and Vollberg TM(1992) Control of squamous differentiation in tracheobronchial and epidermal epithelial cells: role of retinoids. J. Natl. Cancer Inst. Monogr. 13: 93-100

4. Grummer MA and Zachman RD (1998) Retinoic acid and dexamethasone affect RAR-beta and surfactant protein C mRNA in the MLE lung cell line. Am. J. Physiol. 274: L1 - L7

5. Yan C, Ghaffari M, Whitsett JA, Zeng X, Sever Z and Lin S (1998) Retinoic acidreceptor activation of SP-B gene transcription in respiratory epithelial cells. Am. J. Physiol. 275: L239-L246

6. Rearick JI, Deas M and Jetten AM (1987) Synthesis of mucous glycoproteins by rabbit tracheal cells in vitro. Modulation by substratum, retinoids and cyclic AMP. Biochem. J. 242: 19-25

7. Koo JS, Yoon JH, Gray T, Norford D, Jetten AM and Nettesheim P (1999) Restoration of the mucous phenotype by retinoic acid in retinoid-deficient human bronchial cell cultures: changes in mucin gene expression [In Process Citation]. Am. J. Respir. Cell. Mol. Biol. 20: 43-52

8. Koo JS, Jetten AM, Belloni P, Yoon J-H, Kim Y-D and Nettesheim P (1999) The role of nuclear retinoid receptors in the regulation of mucin gene expression in normal tracheobronchial epithelial cells. J. Biochem. 338: 351-357

9. Sueoka N, Lee HY, Walsh GL, Hong WK and Kurie JM (1999) Posttranslational mechanisms contribute to the suppression of specific cyclin: CDK complexes by all-trans retinoic acid in human bronchial epithelial cells. Cancer Res. 59:38383844

10. Massaro GD and Massaro D (1997) Retinoic acid treatment abrogates elastaseinduced pulmonary emphysema in rats [see comments] [published erratum appears in Nat Med 1997 Jul; 3(7):805]. Nat. Med. 3: 675-677

11. Shenai JP, Kennedy KA, Chytil F and Stahlman MT (1987) Clinical trial of vitamin A supplementation in infants susceptible to bronchopulmonary dysplasia. J. Pediatr. 111: 269-277

12. Lippman SM, Benner SE and Hong WK (1994) Retinoid chemoprevention studies in upper aerodigestive tract and lung carcinogenesis. Cancer Res. 54: 2025s-2028s

13. Giguere V (1994) Retinoic acid receptors and cellular retinoid binding proteins: complex interplay in retinoid signaling. Endocr. Rev. 15: 61-79

14. Gebert JF, Moghal N, Frangioni JV, Sugarbaker DJ and Neel BG (1991) High frequency of retinoic acid receptor beta abnormalities in human lung cancer [published erratum appears in Oncogene 1992 Apr; 7(4):821]. Oncogene 6: $1859-1868$

15. Nervi C, Vollberg TM, George MD, Zelent A, Chambon P and Jetten AM (1991) Expression of nuclear retinoic acid receptors in normal tracheobronchial cells and in lung carcinoma cells. Exp. Cell Res. 195: 163-170

16. Haq R, Pfahl M and Chytil F (1991) Differential effects of all-trans and 13-cisretinoic acid on $\mathrm{mRNA}$ levels of nuclear retinoic acid receptors in rat lung and liver. Biochem. Biophys. Res. Commun. 180: 1137-1144 
17. Sun SY, Kurie JM, Yue P, Dawson MI, ShrootB, Chandraratna RA, Hong WK and Lotan R (1999) Differential responses of normal, premalignant, and malignant human bronchial epithelial cells to receptor-selective retinoids. Clin. Cancer Res. 5: $431-437$

18. Sun SY, Yue P, Dawson MI, Shroot B, Michel S, Lamph WW, Heyman RA, Teng M, Chandraratna RA, Shudo K, Hong WK and Lotan R (1997) Differential effects of synthetic nuclear retinoid receptor-selective retinoids on the growth of human non-small cell lung carcinoma cells. Cancer Res. 57: 4931-4939

19. Zhang XK, Liu Y, Lee MO and Pfahl M (1994) A specific defect in the retinoic acid response associated with human lung cancer cell lines. Cancer Res. 54: $5663-$ 5669

20. Picard E, Seguin C, Monhoven N, Rochette-Egly C, Siat J, Borrelly J, Martinet Y, Martinet N and Vignaud JM (1999) Expression of retinoid receptor genes and proteins in non-small-cell lung cancer [see comments]. J. Natl. Cancer Inst. Monogr. 91: 1059-1066

21. Moghal N and Neel BG (1995) Evidence for impaired retinoic acid receptorthyroid hormone receptor AF-2 cofactor activity in human lung cancer. Mol. Cell. Biol. 15: 3945-3959

22. Wu Q, Li Y, Liu R, Agadir A, Lee MO, Liu Y and Zhang X (1997) Modulation of retinoic acid sensitivity in lung cancer cells through dynamic balance of orphan receptors nur77 and COUP-TF and their heterodimerization. EMBO J. 16: $1656-1669$

23. Geradts J, Chen JY, Russell EK, Yankaskas JR, Nieves L and Minna JD (1993) Human lung cancer cell lines exhibit resistance to retinoic acid treatment. Cell Growth Differ. 4: 799-809

24. Kalemkerian GP, Slusher R, Ramalingam S, Gadgeel S and Mabry M (1995) Growth inhibition and induction of apoptosis by fenretinide in small-cell lung cancer cell lines [see comments]. J. Natl. Cancer Inst. Monogr. 87: 1674-1680

25. Shao ZM, Dawson MI, LiXS, Rishi AK, Sheikh MS, Han QX, Ordonez JV, Shroot B and Fontana JA (1995) p53 independent G0/G1 arrest and apoptosis induced by a novel retinoid in human breast cancer cells. Oncogene 11: 493-504

26. Sun SY, Yue P, Shroot B, Hong WK and Lotan R (1997) Induction of apoptosis in human non-small cell lung carcinoma cells by the novel synthetic retinoid CD437. J. Cell. Physiol. 173: 279-284

27. Adachi H, Preston G, Harvat B, Dawson Ml and Jetten AM (1998) Inhibition of cell proliferation and induction of apoptosis by the retinoid AHPN in human lung carcinoma cells. Am. J. Respir. Cell Mol. Biol. 18: 323-333

28. Sun SY, Yue P, Wu GS, El-Deiry WS, Shroot B, Hong WK and Lotan R (1999) Mechanisms of apoptosis induced by the synthetic retinoid CD437 in human nonsmall cell lung carcinoma cells. Oncogene 18: 2357-2365

29. Hsu CA, Rishi AK, Su-LiX, Gerald TM, Dawson MI, Schiffer C, ReichertU, Shroot B, Poirer GC and Fontana JA (1997) Retinoid induced apoptosis in leukemia cells through a retinoic acid nuclear receptor-independent pathway. Blood 89:4470 4479

30. Adachi H, Adams A, Hughes FM, Zhang J, Cidlowski JA and Jetten AM (1998) Induction of apoptosis by the novel retinoid AHPN in human T-cell lymphoma cells involves caspase-dependent and independent pathways. Cell Death Differ. 5: $973-983$

31. Lin Y, Lin B, Agadir A, Liu R, Dawson MI, Reed JC, Fontana JA, BostF, Hobbs PD, Zheng Y, Chen GQ, Shroot B, Mercola D and Zhang XK (1998) Molecular determinants of AHPN (CD437)-induced growth arrest and apoptosis in human lung cancer cell lines. Mol. Cell. Biol. 18: 4719-4731

32. Zou CP, Kurie JM, Lotan D, Zou CC, Hong WKand Lotan R(1998) Higher potency of $\mathrm{N}$-(4-hydroxyphenyl)retinamide than all-trans-retinoic acid in induction of apoptosis in non-small cell lung cancer cell lines. Clin. Cancer Res. 4: 13451355

33. Mologni L, Ponzanelli I, Bresciani F, Sardiello G, Bergamaschi D, Gianni M, Reichert U, Rambaldi A, Terao M and Garattini E (1999) The novel synthetic retinoid 6-[3-adamantyl)-4-hydroxyphenyl]-2-naphthalene carboxylic acid (CD437) causes apoptosis in acute promyelocytic leukemia cells through rapid activation of caspases. Blood 93: 1045-1061

34. Sakaue M, Adachi $\mathrm{H}$ and Jetten AM (1999) Post-transcriptional regulation of MyD118 and GADD45 in human lung carcinoma cells during 6-[3-(1-adamantyl)4-hydroxyphenyl]-2-naphthalene carboxylic acid-induced apoptosis. Mol. Pharmacol. 55: 668-676

35. Schadendorf D, Kern MA, Artuc M, Pahl HL, Rosenbach T, Fichtner I, Nurnberg W, Stuting S, von Stebut E, Worm M, Makki A, Jurgovsky K, Kolde Gand Henz BM (1996) Treatment of melanoma cells with the synthetic retinoid CD437 induces apoptosis via activation of AP-1 in vitro, and causes growth inhibition in xenografts in vivo. J. Cell Biol. 135: 1889-1898
36. Rishi AK, Sun RJ, Gao Y, Hsu CK, Gerald TM, Sheikh MS, Dawson MI, Reichert U, Shroot B, Fornace Jr AJ, Brewer G and Fontana JA (1999) Post-transcriptional regulation of the DNA damage-inducible gadd45 gene in human breast carcinoma cells exposed to a novel retinoid CD437. Nucleic Acids Res. 27: $3111-3119$

37. Oridate N, Higuchi M, Suzuki S, Shroot B, Hong WK and Lotan R (1997) Rapid induction of apoptosis in human C33A cervical carcinoma cells by the synthetic retinoid 6-[3-(1-adamantyl)-4-hydroxyphenyl]-2-naphthalene carboxylic acid (CD437). Int. J. Cancer 70: 484-487

38. Liang JY, Fontana JA, Rao JN, Ordonez JV, Dawson MI, ShrootB, Wilber JF and Feng $P$ (1999) Synthetic retinoid CD437 induces S-phase arrestand apoptosis in human prostate cancer cells LNCaP and PC-3. Prostate 38: 228-236

39. Harvat B and Jetten AM (1999) Growth control by retinoids: regulation of cell cycle progression and apoptosis. Handbook Exp Pharmacol 139: 239-276

40. LuXP, Fanjul A, Picard N, Pfahl M, Rungta D, Nared-Hood K, Carter B, Piedrafita $J$, Tang S and Fabbrizio E (1997) Novel retinoid-related molecules as apoptosis inducers and effective inhibitors of human lung cancer cells in vivo. Nat. Med. 3 : $686-690$

41. Bernard BA, Bernardon JM, Delescluse C, Martin B, Lenoir MC, Maignan J, Charpentier B, Pilgrim WR, Reichert U and Shroot B (1992) Identification of synthetic retinoids with selectivity for human nuclear retinoic acid receptor gamma. Biochem. Biophys. Res. Commun. 186: 977-983

42. Sukhatme VP, Cao XM, Chang LC, Tsai-Morris $\mathrm{CH}$, Stamenkovich D, Ferreira PC, Cohen DR, Edwards SA, Shows TB, Curran T, et al. (1988) A zinc fingerencoding gene coregulated with $\mathrm{c}$-fos during growth and differentiation, and after cellular depolarization. Cell 53: 37-43

43. Changelian PS, Feng P, King TC and Milbrandt J (1989) Structure of the NGFI-A gene and detection of upstream sequences responsible for its transcriptional induction by nerve growth factor. Proc. Natl. Acad. Sci. USA 86: 377-381

44. Christy BA, Lau LF and Nathans D (1988) A gene activated in mouse 3 T3 cells by serum growth factors encodes a protein with "zinc finger" sequences. Proc. Natl. Acad. Sci. USA 85: 7857-7861

45. Lemaire $P$, Vesque $C$, Schmitt J, Stunnenberg H, Frank R and Charnay $P$ (1990) The serum-inducible mouse gene Krox-24 encodes a sequence-specific transcriptional activator. Mol. Cell. Biol. 10: 3456-3467

46. Varnum BC, Lim RW, Kujubu DA, Luner SJ, Kaufman SE, Greenberger JS, Gasson JC and Herschman HR (1989) Granulocyte-macrophage colonystimulating factor and tetradecanoyl phorbol acetate induce a distinct, restricted subset of primary-response TIS genes in both proliferating and terminally differentiated myeloid cells. Mol. Cell. Biol. 9: 3580-3583

47. Liu C, Rangnekar VM, Adamson E and Mercola D (1998) Suppression of growth and transformation and induction of apoptosis by EGR-1. Cancer Gene Ther. 5: $3-28$

48. Li XS, Rishi AK, Shao ZM, Dawson MI, Jong L, Shroot B, Reichert U, Ordonez J and Fontana JA (1996) Posttranscriptional regulation of p21WAF1/CIP1 expression in human breast carcinoma cells. Cancer Res. 56: 5055-5062

49. Hollander MC, Alamo I, Jackman J, Wang MG, McBride OW and Fornace Jr AJ (1993) Analysis of the mammalian gadd45 gene and its response to DNA damage. J. Biol. Chem. 268: 24385-24393

50. Vairapandi M, Balliet AG, Fornace Jr AJ, Hoffman B and Liebermann DA (1996) The differentiation primary response gene MyD118, related to GADD45, encodes for a nuclear protein which interacts with PCNA and p21WAF1/CIP1. Oncogene 12: 2579-2594

51. Harada $\mathrm{H}$, Taniguchi T and Tanaka N (1998) The role of interferon regulatory factors in the interferon system and cell growth control. Biochimie 80: 641-650

52. Tanaka N, Ishihara M, Kitagawa M, HaradaH, Kimura T, Matsuyama T, Lamphier MS, Aizawa S, Mak TW and Taniguchi T (1994) Cellular commitment to oncogene-induced transformation or apoptosis is dependent on the transcription factor IRF-1. Cell 77: 829-839

53. Liu C, Calogero A, Ragona G, Adamson E and Mercola D (1996) EGR-1, the reluctant suppression factor: EGR-1 is known to function in the regulation of growth, differentiation, and also has significant tumor suppressor activity and a mechanism involving the induction of TGF-beta1 is postulated to account for this suppressor activity. Crit. Rev. Oncog. 7: 101-125

54. Sun SY, Yue P, Wu GS, El-Deiry WS, Shroot B, Hong WK and Lotan R (1999) Implication of $p 53$ in growth arrestand apoptosis induced by the synthetic retinoid CD437 in human lung cancer cells. Cancer Res. 59: 2829-2833 
55. Rolli M, Kotlyarov A, Sakamoto KM, Gaestel M and Neininger A (1999) Stressinduced stimulation of early growth response gene- 1 by $\mathrm{p38} /$ stress-activated protein kinase 2 is mediated by a cAMP-responsive promoter element in a MAPKAP kinase 2-independent manner. J. Biol. Chem. 274: 19559-19564

56. de Belle I, Huang RP, Fan Y, Liu C, Mercola D and Adamson ED (1999) p53 and Egr-1 additively suppress transformed growth in HT1080 cells but Egr-1 counteracts p53-dependent apoptosis. Oncogene 18: 3633-3642

57. Yan SF, Lu J, Zou YS, Soh-Won J, Cohen DM, Buttrick PM, Cooper DR Steinberg SF, Mackman N, Pinsky DJ and Stern DM (1999) Hypoxia-associated induction of early growth response-1 gene expression. J. Biol. Chem. 274: $15030-15040$

58. Hodge C, Liao J, Stofega M, Guan K, Carter-Su C and Schwartz J (1998) Growth hormone stimulates phosphorylation and activation of elk-1 and expression of cfos, egr-1, and junB through activation of extracellular signal-regulated kinases 1 and 2. J. Biol. Chem. 273: 31327-31336

59. Lim CP, Jain $\mathrm{N}$ and Cao X (1998) Stress-induced immediate-early gene, egr-1, involves activation of p38/JNK1. Oncogene 16: 2915-2926

60. Zhang Y, Huang Y, Rishi AK, Sheikh MS, Shroot B, ReichertU, Dawson M, Poire G and Fontana JA (1999) Activation of the p38 and JNK/SAPK mitogen-activated protein kinase pathways during apoptosis is mediated by a novel retinoid. Exp. Cell Res. 247: 233-240

61. Matsuura H, Sakaue M, Subbaramaih K, Kamitani H, Eling TE, Dannenberg AJ, Tanabe T, Inoue H, Arata J and Jetten AM (1999) Regulation of cyclooxygenase2 by interferon gamma and transforming growth factor alpha in normal human epidermal keratinocytes and squamous carcinoma cells. Role of mitogenactivated protein kinases. J. Biol. Chem. 274: 29138-29148

62. Kaneda N, Oshima M, Chung SY and Guroff G (1992) Sequence of a rat TIS11 cDNA, an immediate early gene induced by growth factors and phorbol esters. Gene 118: 289-291

63. Gashler A and Sukhatme VP (1995) Early growth response protein 1 (Egr-1): prototype of a zinc-finger family of transcription factors. Prog. Nucleic Acid Res. Mol. Biol. 50: $191-224$

64. Lai WS, Carballo E, Strum JR, Kennington EA, Phillips RS and Blackshear PJ (1999) Evidence that tristetraprolin binds to AU-rich elements and promotes the deadenylation and destabilization of tumor necrosis factor alpha mRNA. Mol. Cell. Biol. 19: $4311-4323$

65. Fornace Jr AJ (1992) Mammalian genes induced by radiation; activation of genes associated with growth control. Annu. Rev. Genet. 26: 507-526

66. Sun SY, Yue P, Shroot B, Hong WK and Lotan R (1999) Implication of c-Myc in apoptosis induced by the retinoid CD437 in human lung carcinoma cells. Oncogene 18: 3894-3901

67. Muthukkumar S, Nair P, Sells SF, Maddiwar NG, Jacob RJ and Rangnekar VM (1995) Role of EGR-1 in thapsigargin-inducible apoptosis in the melanoma cell line A375-C6. Mol. Cell. Biol. 15: 6262-6272

68. Nair P, Muthukkumar S, Sells SF, Han SS, Sukhatme VP and Rangnekar VM (1997) Early growth response-1-dependent apoptosis is mediated by p53. J. Biol. Chem. 272: 20131-20138
69. Huang RP, Liu C, Fan Y, Mercola D and Adamson ED (1995) Egr-1 negatively regulates human tumor cell growth via the DNA-binding domain. Cancer Res. 55: 5054-5062

70. Levin WJ, Press MF, Gaynor RB, Sukhatme VP, Boone TC, Reissmann PT, Figlin RA, Holmes EC, Souza LM and Slamon DJ (1995) Expression patterns of immediate early transcription factors in human non-small cell lung cancer. The Lung Cancer Study Group. Oncogene 11: 1261-1269

71. Nagarajan L, Zhao L, Lu X, Warrington JA, Wasmuth JJ, Siciliano M, Deisseroth $A B$ and Liang JC (1994) 5q-chromosome. Evidence for complex interstitial breaks in a case of refractory anemia with excess blasts. Cancer Genet. Cytogenet. 74: 8-12

72. Piedrafita FJ and Pfahl M (1997) Retinoid-induced apoptosis and Sp1 cleavage occur independently of transcription and require caspase activation. Mol. Cell. Biol. 17: $6348-6358$

73. Ahmed MM, Sells SF, Venkatasubbarao K, Fruitwala SM, Muthukkumar S, Harp C, Mohiuddin M and Rangnekar VM (1997) lonizing radiation-inducible apoptosis in the absence of p53 linked to transcription factor EGR-1. J. Biol. Chem. 272: 33056-33061

74. Chiu JJ, Wung BS, Hsieh HJ, Lo LW and Wang DL (1999) Nitric oxide regulates shear stress-induced early growth response-1. Expression via the extracellular signal-regulated kinase pathway in endothelial cells. Circ. Res. 85: 238-246

75. Delescluse C, Cavey MT, Martin B, Bernard BA, Reichert U, Maignan J, Darmon $M$ and Shroot B (1991) Selective high affinity retinoic acid receptor alpha or betagamma ligands. Mol. Pharmacol. 40: 556-562

76. Marchetti P, Zamzami N, Joseph B, Schraen-Maschke S, Mereau-Richard C, Costantini P, Metivier D, Susin SA, Kroemer G and Formstecher P (1999) The novel retinoid 6-[3-(1-adamantyl)-4-hydroxyphenyl]-2-naphthalene carboxylic acid can trigger apoptosis through a mitochondrial pathway independent of the nucleus. Cancer Res. 59: 6257-6266

77. Li H, Kolluri SK, Gu J, Dawson MI, Cao X, Hobbs PD, Lin B, Chen G, Lu J, Lin F, Xie Z, Fontana JA, Reed JC and Zhang X (2000) Cytochrome c release and apoptosis induced by mitochondrial targeting of nuclear orphan receptor TR3. Science 289: $1159-1164$

78. Fanjul A, Dawson MI, Hobbs PD, Jong L, Cameron JF, Harlev E, Graupner G, Lu XP and Pfahl M (1994) A new class of retinoids with selective inhibition of AP-1 inhibits proliferation. Nature 372: 107-111

79. Lehmann JM, Jong L, Fanjul A, Cameron JF, Lu XP, Haefner P, Dawson MI and Pfahl M (1992) Retinoids selective for retinoid X receptor response pathways. Science 258: $1944-1946$

80. Zhang J, Alter N, Reed JC, Borner C, Obeid LM and Hannun YA (1996) Bcl-2 interrupts the ceramide-mediated pathway of cell death. Proc. Natl. Acad. Sci. USA 93: $5325-5328$ 